\title{
RANCANGAN SISTEM PENYEMPROT PLASMA UNTUK PEMBUATAN SEL BAHAN BAKAR OKSIDA PADAT : STUDI PEMANASAN PARTIKEL YSZ DALAM PLASMA JET
}

Widdi Usada, Suryadi, Agus Purwadi

Pustek Akselerator dan Proses Bahan

Jl. Babarsari Kotak Pos 6101 Ykbb 55231

\begin{abstract}
ABSTRAK
RANCANGAN SISTEM PENYEMPROT PLASMA UNTUK PEMBUATAN SEL BAHAN BAKAR OKSIDA PADAT : STUDI PEMANASAN PARTIKEL YSZ DALAM PLASMA JET. Salah satu metode pembuatan elektrolit YSZ pada SOFC adalah dengan penyemprot plasma. Sistem ini memanaskan partikel sehingga meleleh dan mendorong partikel tersebut sampai di target dan membentuk lapisan. Makalah ini menyajikan studi pemanasan partikel YSZ dalam plasma jet. Dengan model sederhana dapat ditunjukkan waktu yang diperlukan untuk melelehkan serbuk partikel YSZ dengan ukuran butir $50 \mu \mathrm{m}$ sekitar $12.10^{-4}$ detik.

Kata kunci : plasma, penyemprot, transfer panas, sel bahan bakar oksida padat, elektrolit YSZ.
\end{abstract}

\section{ABSTRACT}

CONCEPT OF PLASMA SPRAYING SYSTEM FOR SOLID OXIDE FUEI CELL: HEATING STUDIES OF YSZ PARTICLE IN PLASMA JET. One of several methods to build YSZ electrolyte of SOFC is plasma spraying. This system heats particle to a melting point and then pushing them into target and forming a deposition. This paper presents heating studies of YSZ particle in plasma jet. By simple model it is shown that the required time such those YSZ particle with grain size of $50 \mu \mathrm{m}$ to be melt is around $12 \times 10^{-4}$ second.

Keywords : plasma, spraying, heat transfer, SOFC, YSZ electrolyte

\section{PENDAHULUAN}

T untutan kebutuhan energi ramah lingkungan semakin memberikan dorongan untuk memperoleh energi cukup murah dan berlimpah tanpa membuat kerusakan lingkungan merupakan tantangan berat bagi negara di seluruh dunia. Tampaknya kebutuhan energi lebih dominan daripada kenyamanan lingkungan sehingga segala upaya telah dilakukan dengan mengeksploitasi secara besar-besaran sumber-sumber cadangan yang ada di dunia ini, seperti yang dilakukan pemerintah Amerika yang akan mengeskploitasi cadangan minyak di Alaska, padahal Alaska menurut para ahli lingkungan diharapkan sebagai penyeimbang suhu dunia, maupun di negara lain melalui perusahaan-perusahaan padat modal. ${ }^{[1,2]}$

Dominasi faktor kebutuhan energi dibanding dampak terhadap lingkungan memaksa banyak negara di Asia memproyeksikan pemenuhan kebutuhan energi untuk tahun 2020 sesuai dengan cadangan energi yang dipunyainya seperti Negara Cina, India, Indonesia mengandalkan batu bara sebesar 50-80 \% dari kebutuhan energi, Malaysia dan Thailand dengan gas sebagai andalan, Singapura mengimpor lebih $90 \%$ kebutuhan minyaknya, Korea, Jepang, Taiwan mengandalkan modal untuk mengimpor batubara dan minyak. ${ }^{[3]}$ Yang paling menarik adalah Vietnam lebih 50 \% diharapkan kebutuhan energi dari energi air. Jadi sampai tahun 2020 masalah lingkungan dan dampaknya akan menjadi masalah serius bila kebijakan tersebut tetap dilaksanakan khususnya masalah polusi $\mathrm{SO}_{x}$ dan $\mathrm{NO}_{x}$ serta $\mathrm{CO}_{x}$ yang dihasilkan batu bara.

Tahun 2002 kapasitas energi listrik di Indonesia sekitar 39.6 gigawatt dengan rincian $94 \%$ disuplai dari tenaga termal, $4 \%$ dari tenaga air, dan $2 \%$ dari geotermal. Kapasitas energi termal sekitar $37 \mathrm{GW}$ disuplai dari minyak bumi sebesar $54 \%$, Gas $23 \%$ dan batu bara $17 \%$. Dengan laju kenaikan kebutuhan rata-rata sebesar 10 $\%$ dan dengan kebijakan penekanan pemakaian minyak bumi maka penggunaan batu bara akan meningkat pesat dengan pertimbangan cadangan batu bara masih cukup besar dan diperkirakan mampu memberikan pasokan sampai 50 tahun ${ }^{[4]}$ Ditemukannya ladang baru di Blok Cepu dengan perkiraan cadangan sekitar $0.6-1.2 \mathrm{Mbarrel}$, ${ }^{[5]}$ sedikit memberikan kelegaan. Meski demikian banyak faktor yang harus diperhatikan secara serius yaitu pertama, kekayaan mineral energi kita sangat kecil, sebagai contoh untuk minyak sekitar $1 \%$ dan batu bara sekitar $3 \%$ dari cadangan dunia, kedua lebih dari $92 \%$ kekayaan minyak di Indonesia dieksploitasi oleh pihak asing, ketiga perlunya peninjauan kembali perjanjian yang lebih adil sehingga gejolak komunal tidak muncul, keempat penyiapan tenaga ahli yang lambat untuk mengeksploitasi dan mengeksplorasi kekayaan negeri sendiri, 
kelima perlunya diputuskan secara bulat pilihan energi alternatif seperti nuklir, sel surya, sel tunam (sel bahan bakar) dan lain sebagainya.

Menyikapi masalah tersebut maka pemerintah melalui Departemen ESDM mengeluarkan Program Kebijakan Energi Nasional khususnya bidang energi non-konvensional (angin, gelombang, matahari, sel tunam di luar tenaga hidro dan biofuels) yang diharapkan tahun 2020 memberikan sumbangan sebesar $5 \%$ dari kebutuhan energi nasional, maka Konferensi Fuel Cell Indonesia mengajak institusi-institusi yang berminat dalam sel tunam untuk berusaha keras memenuhi program tersebut.

Sel tunam merupakan sumber energi baru yang sangat menjanjikan karena di samping tidak mempunyai dampak lingkungan yang berarti, juga bahan bakar berlimpah dan efisiensi tenaga tinggi. Bahan bakar berlimpah karena bahan bakar utamanya adalah hidrogen dan oksigen, dan produk hasil olah piranti sel tunam dari reaksi hidrogen dan oksigen adalah air.

Sejarah perkembangan sel tunam menuju minimalisasi harga, ukuran, berat, resiko mengarah pada dibutuhkannya material baru dan mengarah pada keramik dan campurannya. Sel tunam dengan komponen keramik disebut sel tunam oksida padat dengan logam dari unsur tanah jarang sebagai basisnya. Kendala utama penggunaan oksida padat adalah suhu operasi yang relatif tinggi (sekitar $1000{ }^{\circ} \mathrm{C}$ ), meskipun hasil penelitian terakhir dapat dicapai sekitar $650{ }^{\circ} \mathrm{C}$.

Mengacu Kebijakan Energi Nasional, maka perlu penguasaan litbang sumber energi baru dan terbarukan khususnya sel surya dan sel bahan bakar oksida padat.

\section{SISTEM PENYEMPROT PASMA}

Sel tunam adalah sistem penyedia energi listrik yang mengandalkan reaksi kimia pembentukan air . Sebagai bahan bakar adalah gas hidrogen dan oksigen. Sel tunam terdiri dari anoda, elektrolit dan katoda. Anoda berfungsi mengubah gas hidrogen menjadi ion hidrogen bermuatan positif dan elektron, sedangkan katoda mengubah gas oksigen menjadi ion oksigen bermuatan negatif. Untuk sel tunam dengan elektrolit padat, maka ion oksigen berjalan melalui elektrolit padat tersebut dan bertemu dengan ion hidrogen membentuk air. Berbagai teknik digunakan untuk pembuatan komponen SOFC diantaranya adalah dengan teknik plasma spraying dan sputtering dan teknik plasma ablasi dengan laser. Dari berbagai teknik yang ada tersebut yang dibahas pada makalah ini adalah teknologi plasma spraying. Teknologi plasma spraying adalah pelucutan plasma untuk pemanasan butiran bahan komponen yang dimasukkan dalam susunan piranti pelucut plasma dengan kecepatan tinggi seperti diperlihatkan Gambar 1. [7] Partikel dalam plasma menempel membentuk lapisan. Bila lapisan bahan yang dimasukkan adalah bahan anoda misalkan paduan Ni-YSZ maka terbentuk anoda lapisan Ni-YSZ, dan kemudian bila yang dimasukkan butir bahan YSZ maka di atas lapisan Ni-YSZ terbentuk lapisan elektrolit YSZ, dan seterusnya bila yang dimasukkan butir bahan LaMnSr akan terbentuk lapisan katoda.

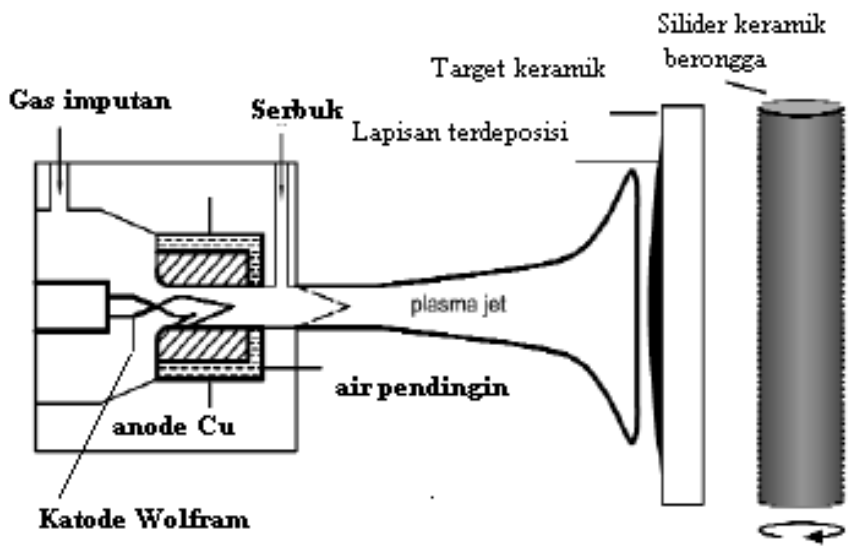

Gambar 1. Sistem Penyemprot Plasma 
Dengan sistem penyemprot plasma tersebut maka dapat diperoleh lapisan anoda dari bahan NiYSZ, lapisan berikutnya adalah elektrolit YSZ dan lapisan terakhir adalah katoda dari bahan LaMnSr. Dengan ketiga lapisan tersebut diperoleh sel tunam oksida padat.

SEL BAHAN BAKAR OKSIDA PADAT

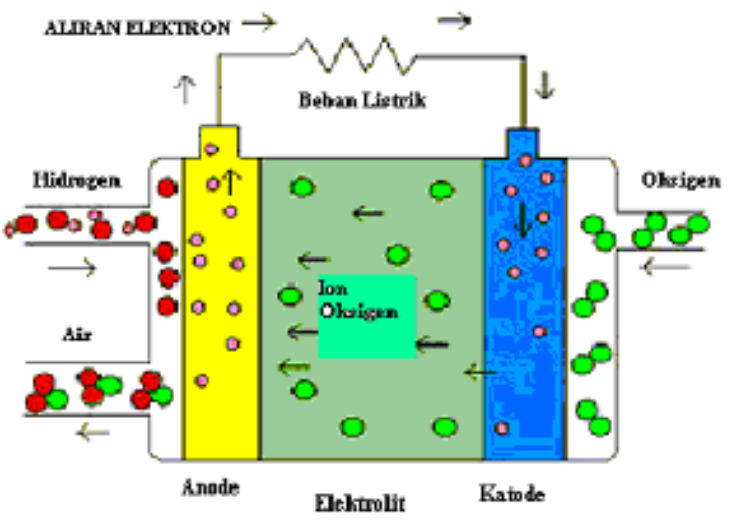

Gambar 2. Sel Tunam Oksida Padat

Gambar 2. memperlihatkan sel tunam oksida padat dan proses pembentukan energi listrik. Pada Gambar 2 diperlihatkan bahwa elektron dan ion hidrogen dihasilkan oleh anoda yang berfungsi sebagai katalisator saat gas hidrogen dimasukkan ke anoda. Elektron yang terbentuk di anoda akan mengalir melewati beban listrik menuju katoda, di katoda ini elektron bercampur dengan gas oksigen membentuk ion oksigen. Ion oksigen akan mengalir di dalam elektrolit padat dan sampai di anoda, ion oksigen ini akan bereaksi dengan ion hidrogen dan membentuk senyawa $\mathrm{H}_{2} \mathrm{O}$ (air).

Beda potensial listrik antara kedua elektroda yang disebabkan kelebihan elektron di anoda dan di katode, menimbulkan arus listrik melalui beban luar sehingga menjadikan sel tunam sebagai sumber daya listrik.

Tabel 1 memperlihatkan karakteristik tipikal sebuah sel tunam oksida padat. Agar sel tunam berfungsi maka peranan utama elektrolit adalah dapat mengalirkan ion oksigen yang bermuatan negatif, sedangkan ion positif ataupun atom lainnya tidak boleh lewat. Oleh karena persyaratan pembentukan lapisan YSZ sebagai elektrolit antara lain adalah porositas mendekati nol. Untuk mendapatkan lapisan dengan porositas sedemikian kecil dengan teknik penyemprotan plasma tidak mudah, dan usaha untuk mendapatkan lapisan dengan nilai porositas tinggi adalah partikel berukuran sekecil mungkin dan diharapkan serbuk partikel tersebut seluruhnya meleleh saat dalam plasma jet.

Tabel 1. Karakteristik Tipikal Sel Tunam Oksida Padat

\begin{tabular}{|l|l|}
\hline Parameter & Nilai Karakteristik \\
\hline Rapat Daya & $0.75-1.1 \mathrm{~W} / \mathrm{cm}^{2}$ \\
\hline Rapat Arus & $1-2 \mathrm{~A} / \mathrm{cm}^{2}$ \\
\hline Tegangan & $0.9-1$ volt \\
\hline Bahan dan tebal elektrolit & $\mathrm{CaSZ}$ atauYSZ, $10-150 \mu \mathrm{m}$ \\
\hline Bahan dan tebal anoda & $\mathrm{Ni}-\mathrm{YSZ}, 0.5-1 \mathrm{~mm}$ \\
\hline Bahan dan tebal katoda & $\mathrm{LSM}, 50 \mu \mathrm{m}$ \\
\hline
\end{tabular}

Dengan karakteristik tipikal seperti di atas maka teknik pembuatan komponen struktur sel tunam dengan plasma sputtering dan teknik laser ablasi tidak begitu baik karena laju deposisi sangat rendah, sehingga teknik pembuatan dengan sistem plasma spraying lebih baik. Seperti diketahui bahwa di dalam sistem penyemprot plasma pada umumnya distribusi suhu dan kerapatan mendekati gaussian atau sinus seperti diperlihatkan Gambar 3. Suhu ke arah pusat nozzle dan ke arah sumbu z biasanya maksimum dan menurun saat menyebar ke 
arah posisi radial, jadi dengan demikian sangat sulit diharapkan diperoleh suatu lapisan terbentuk yang bersifat uniform, dan diperlukan peran "tuning" pada sistem penyemprot plasma sehingga lapisan terbentuk bisa uniform.

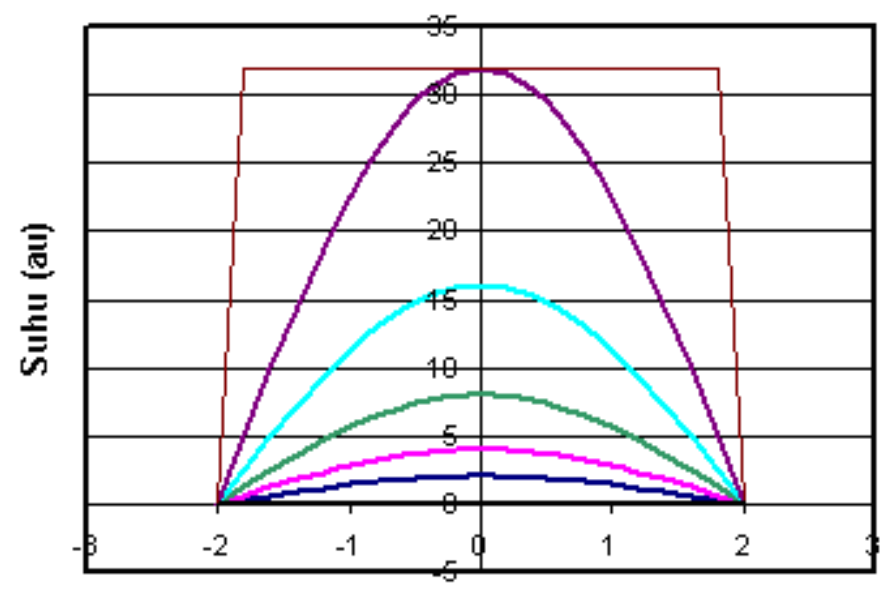

Posisi Radial (au)

Gambar 3. Kurva distribusi suhu plasma jet sebagai fungsi posisi radial

Situasi paling sederhana dalam proses transfer panas tak tunak adalah dengan mengabaikan distribusi suhu di dalam padatan dan hanya ditinjau transfer panas antara padatan dengan fluida ambangnya saja. Dengan kata lain, akan diandaikan suhu dalam padatan tetap dan sama dengan suhu permukaannya, metode ini disebut lumped capacitance methode. Pengandaian diterapkan dalam suatu proses yang terjadi pada plasma spray yaitu adanya proses injeksi partikel lembut ke dalam plasma jet yang suhunya sangat tinggi. Partikel-partikel tersebut diharapkan akan meleleh dan jatuh di permukaan dan memadat membentuk suatu lapisan.

\section{DASAR TEORI}

Dengan metode lumped capacitance maka proses transfer panas dari plasma jet dengan suhu $T_{\infty}$ sehingga suhu permukaan butir partikel berbentuk bola dengan luas permukaan $A_{s}$ dengan suhu mula-mula $T_{i}$ akan sama dengan suhu lelehnya $T$ akan diperoleh persamaan sebagai berikut ${ }^{[8,9]}$

$$
\frac{T(t)-T_{\infty}}{T_{i}-T_{\infty}}=\exp \left[-\left(\frac{h A_{s}}{\rho V c_{p}}\right) t\right]
$$

Persamaan (1) ini menggambarkan suhu partikel $T(t)$ sebagai fungsi dari suhu plasma jetnya $T_{\infty}$, suhu mula-mula partikel $T_{i}$, dan juga fungsi tetapan konveksi $h$, luas permukaan partikel $A_{s}$, waktu $(t)$, massa jenis $\rho$, dan kapasitas panas $c_{p}$, serta volume partikel $V$ seperti diperlihatkan Gambar 4. Dengan persamaan (1) ini dapat digambarkan proses perubahan suhu partikel karena pemanasan partikel oleh plasma jet dengan berbagai variasi seperti ukuran partikel.



Gambar 4. Kesetimbangan energi yang masuk dengan yang tersimpan 
Seperti telah disebutkan di depan bahwa untuk mendapatkan lapisan yang seragam diharapkan partikel seluruhnya meleleh jadi tidak hanya di permukaan saja,maka proses selanjutnya adalah proses pelelehan partikel, jadi setelah partikel mencapai suhu leleh maka panas dari plasma jet tidak akan menaikkan suhu partikel lagi. Demikian pula panas tersebut akan diserab oleh partikel padat sebagai panas yang mengakibatkan menjadi terleleh. Waktu yang diperlukan oleh plasma jet untuk melelehkan seluruh partikel ditunjukkan persamaan berikut ini

$$
t_{2}-t_{1}=\frac{\rho V h_{s f}}{h A_{s}\left(T_{\infty}-T_{m e l t}\right)}
$$

\section{HASIL DAN PEMBAHASAN}

Untuk partikel YSZ (8 mole $\% \mathrm{Y}_{2} \mathrm{O}_{3}$ dalam 92 mole $\% \mathrm{ZrO}_{2}$ ) bentuk bola dengan diameter $D=50 \mu \mathrm{m}$, kerapatan $\rho 5940 \mathrm{~kg} \cdot \mathrm{m}^{-3}$, konduktivitas termal $k=1.62 \mathrm{~W} / \mathrm{mK}$ dan kapasitas panas $c_{p} \quad 470 \mathrm{~J} / \mathrm{kg} \mathrm{K}$, dan suhu awal $T_{i} 300 \mathrm{~K}$. Plasma dipertahankan pada suku $T_{\infty} 10000 \mathrm{~K}$ koefisien konveksi $h 30000 \mathrm{~W} / \mathrm{m}^{2} \mathrm{~K}$. Bila suhu leleh YSZ $3000 \mathrm{~K}$ dan bila dengan panas lebur $h_{\text {sf }} 4000 \mathrm{~kJ} / \mathrm{kg}$, maka perlu diketahui berapakah waktu yang diperlukan untuk memanaskan partikel sampai meleleh dan waktu yang diperlukan partikel tersebut melebur semua setelah ia mencapai titik lelehnya. Untuk itu perlu juga diketahui mengapa partikel tersebut mengikuti aliran plasma jet dan berapa besar kecepatannya dan apakah mempunyai kecepatan yang sama dengan plasma jetnya, serta apakah plasma jet mempunyai kecepatan yang uniform.

Dengan persamaan (1) dan dengan bantuan perangkat lunak seperti micrsosoft excel dapat disusun aritmatik sederhana dengan menjalankan penambahan waktu sehingga proses pemanasan dari plasma jet ke partikel dapat digambarkannya, sehingga diperoleh distribusi suhu sebagai fungsi waktu pemanasan dengan berbagai variasi diameter partikel diperlihatkan Gambar 5 .

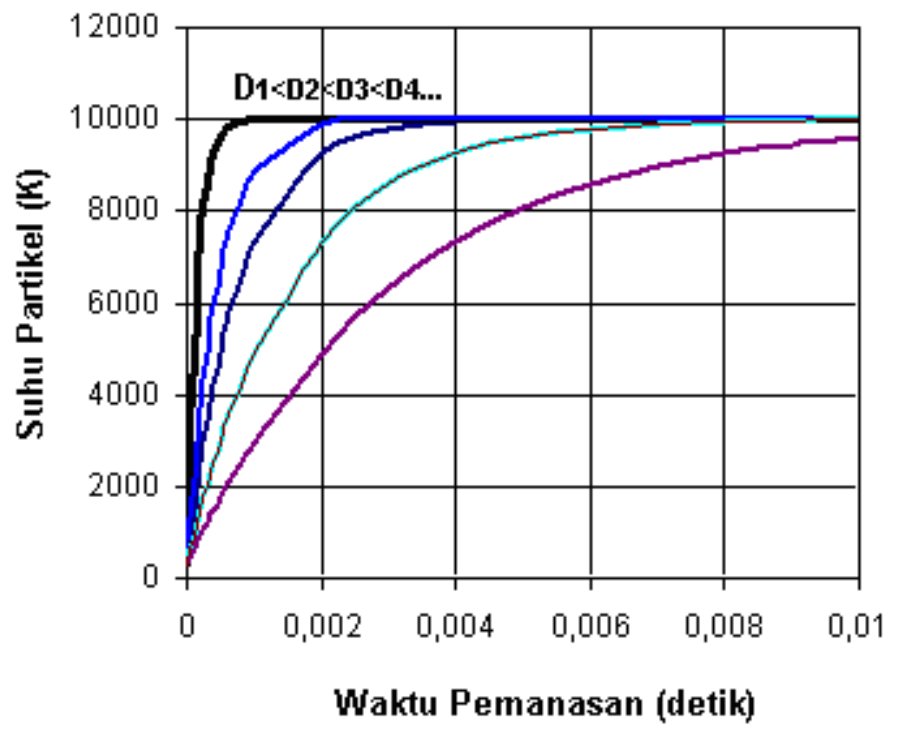

Gambar 5. Distribusi suhu sebagai waktu pemanasan

Pada Gambar 5 dapat diketahui bahwa suhu partikel akan naik tajam secara eksponensial pada suhu antara $300 \mathrm{~K}$ sampai dengan $10000 \mathrm{~K}$ dalam waktu yang sangat cepat sekali $(<0.01$ detik). Dengan variasi diameter partikel yang semakin kecil maka semakin cepat waktu yang diperlukan plasma jet untuk melelehkan partikel.

Sedangkan bila suhu plasma jet $T_{\infty}$ diubah dengan berbagai variasi dari $10000 \mathrm{~K}, 8000 \mathrm{~K}, 6000 \mathrm{~K}$ dan 4000 $\mathrm{K}$, maka diperoleh hasil seperti diperlihatkan Gambar 6. Semakin panas suhu plasma jet akan lebih efisien karena 
dengan semakin tinggi suhu plasma jet semakin cepat partikel dengan suhu tinggi sampai di permukaan yang dilapisi.

Kembali kepada pemanasan partikel dengan suhu plasma jet sekitar $10000 \mathrm{~K}$, maka untuk setiap butir partikel meleleh seluruhnya maka dengan persamaan (2) akan diperoleh waktu yang diperlukan oleh plasma untuk melelehkan seluruh isi butir partikel.

$$
t_{2}-t_{1}=9.4 \times 10^{-4} \quad \operatorname{detik}
$$

Jadi dalam selang waktu tertentu suhu partikel energi panas seluruhnya digunakan untuk melelehkan sehingga ada selang waktu tertentu suhu partikel tetap, baru setelah melewati waktu tersebut suhu partikel naik lagi sesuai dengan transfer panas yang diberikan oleh plasma jet. Dengan memasukkan hasil di atas maka distribusi suhu partikel dengan memasukkan proses pelelehan diperlihatkan Gambar 7.

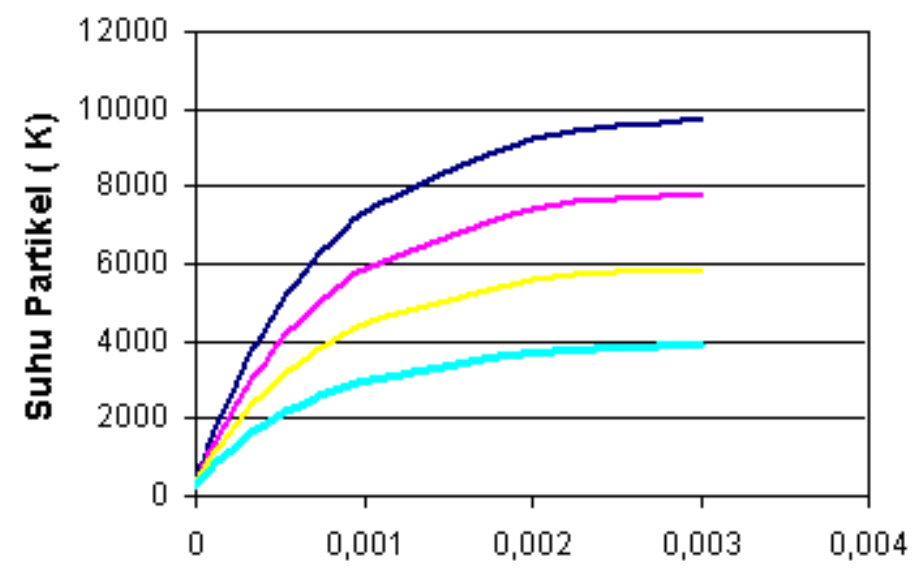

Waktu Pemanasan (detik)

Gambar 6. Kurva pemanasan partikel YSZ berukuran $50 \mu \mathrm{m}$ sebagai fungsi waktu pemanasan dengan berbagai variasi suhu plasma jet $10000,8000,6000$ dan $4000 \mathrm{~K}$

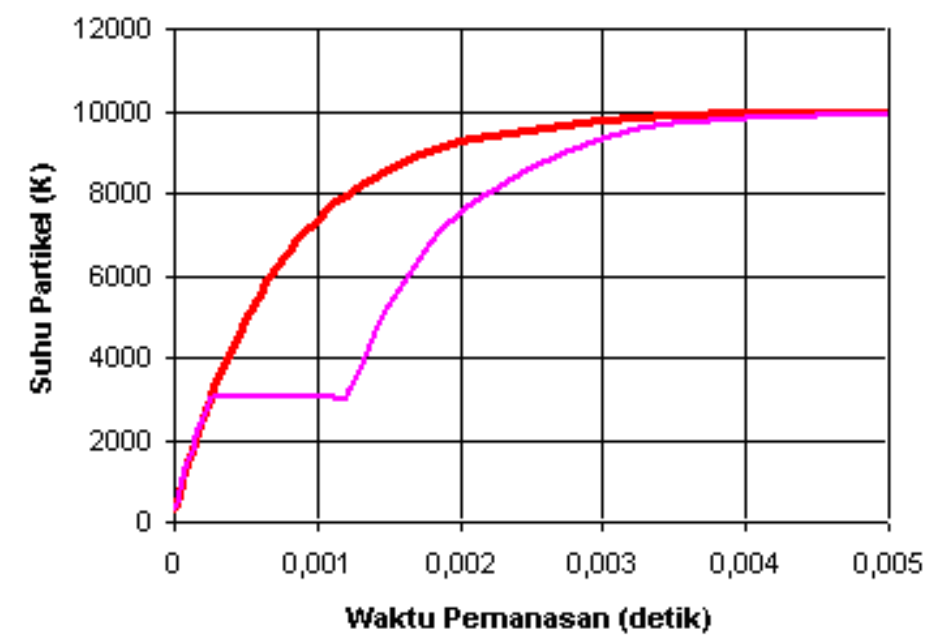

Gambar 7. Suhu partikel YSZ bentuk bola berdiameter $50 \mu \mathrm{m}$ dalam plasma jet bersuhu $10000 \mathrm{~K}$ sebagai fungsi waktu pemanasan tanpa dan dengan proses pelelehan. 
Pada Gambar 7 tampak bahwa dalam waktu 0.00026 detik suhu leleh telah dicapai, namun belum menunjukkan seluruh partikel meleleh. Oleh karena itu ingin diketahui berapa waktu yang diperlukan untuk melelehkan seluruh partikel. Parameter waktu yang diperlukan sehingga partikel seluruhnya meleleh ini sangat penting agar partikel yang terdeposit benar-benar merupakan deposisi lelehan partikel sehingga diperoleh lapisan yang uniform, hal ini sangat berbeda bila lapisan terdeposisi merupakan kumpulan butir-butir partikel sehingga kemungkinan terjadi batas butir sedemikian banyak dan akhirnya lapisan terbentuk mudah patah disamping itu sifatnya tidak lagi sama.

Disimpulkan diperlukan waktu tambahan lagi selama $9.4 \times 10^{-4}$ detik agar partikel seluruhnya meleleh. Jadi waktu keseluruhan yang diperlukan untuk meleburkan partikel seluruhnya adalah $12 \times 10^{-4}$ detik. Oleh karena itu proses pelelehan partikel seluruhnya diperlihatkan Gambar 7 dengan kurva warna birunya.

\section{KESIMPULAN}

Untuk memahami permasalahan dalam sistem penyempot plasma, maka pendekatan yang dapat digunakan adalah suhu plasma jet tetap tidak tergantung waktu dan tempat, dan interaksi plasma jet dengan partikel harus memenuhi kesetimbangan tenaga yang masuk sama dengan tenaga yang tersimpan di dalam partikel. Dengan pendekatan tersebut dapat diketahui distribusi suhu partikel sebagai fungsi waktu dan akhirnya diketahui pula waktu yang diperlukan agar semua partikel meleleh. Parameter yang diperoleh ini sangat penting sebagai masukan dalam perancangan sistem penyemprot plasma. Untuk memperoleh proses pemindahan panas yang baik maka diperlukan pengecilan ukuran butir partikel tersebut, sehingga bila ukuran butir partikel tersebut dalam orde nano akan diperoleh waktu pemanasan yang sangat efisien dan hasil pelapisan juga semakin bagus. Dengan semakin kecil ukuran butir dan semakin besar suhu plasma jet maka semakin kecil waktu pemanasan, juga semakin kecil waktu pelelehan, dengan demikian waktu kontak partikel terleleh dengan pengotor selama dalam perjalanan juga semakin kecil, dan lapisan terbentuk seragam sehingga diharapkan diperolehnya pelapisan yang seragam dan bebas pengotor.

\section{DAFTAR PUSTAKA}

1. VOA, edisi bahasa Indonesia, Kongres AS Setujui RUU Energi dan Pengeboran Minyak di Alaska, 8 Februari 001, www.voanews.com/indonesia.

2. Beritaiptek.com, Cadangan Minyak Tipis, Pemerintah Lambat Antisipasi, Senin 27 Juni 2005, www.beritaiptek.com

3. WIDDI USADA DKK., Kajian Pustaka Prospek Pengembangan Sel Bahan Bakar Oksida Padat, Ganendra, Vol. IV, No. 2, Juli 2001.

4. DEPARTEMEN ESDM, Kebijakan Batubara Nasional,2004

5. KWIK KIAN GIE, Eksploitasi Cepu oleh Asing : Akhir Sebuah Legenda, 1 Juni, 2005, Tanjung Binga

6. WIDDI USADA DKK, Preparasi Sarana dan Prasarana Pembuatan Sel Tunam Oksida Padat di P3TM-BATAN, Prosiding Seminar Nasional :"Teknologi Tepatguna Penghasil Energi Alternatif Sebagai Solusi Penghematan Pemakaian BBM", UMY 30 Juli 2005, ISBN 979-99844-0-8.

7. VARDELLE, M. et al., Coating Generation : Vaporization of Particles in Plasma Spraying and Splat Formation, Pure \& Appl. Chem. Vol. 68, No. 6, pp. 1093-1099, printed in Great Britain, 1996.

8. GUY DELLUC, et al, Fast Modelling of Plasma Jet and Particle Behaviours in Spray Conditions, SPCTS, UMR-CNRS 6638 University of Limoges, 123, Avenue Albert Thomas 87060 Limoges Cedex, France,

9. NN, Plasma Spray Lecture Notes,in http://www.eng.fsu.edu/ shih/eml3016/ lecture-notes/unsteady \%20heat $\% 20$ transfer 